\title{
ASSESSING THE MOBILITY OF CLAY MATERIALS USED IN THE CONSTRUCTION OF ENGINEERED SAFETY BARRIERS FOR RADIOACTIVE WASTE DISPOSAL
}

\author{
Maryinskikh S. G. ${ }^{1,2}$, Zhigarev V. V. ${ }^{1}$, Ilyina O. A. ${ }^{3}$, Krupskaya V. V. ${ }^{4,5}$ \\ ${ }^{1}$ Bentonite Company Ltd, Moscow, Russia \\ ${ }^{2}$ FSBEI of HE Industrial University of Tyumen, Tyumen, Russia \\ ${ }^{3}$ Bentonite of Khakassia Ltd, Chernogorsk, Republic of Khakassia, Russia \\ ${ }^{4}$ Nuclear Safety Institute of the Russian Academy of Sciences, Moscow, Russia \\ ${ }^{5}$ Institute of Geology of Ore Deposits, Petrography, Mineralogy and Geochemistry of the Russian Academy of Sciences, \\ Moscow, Russia
}

Article received on July 19, 2021

\begin{abstract}
Large-scale efforts implemented under the Unified State System for RW Management including the construction of near-surface disposal facilities for RW Class 3 and 4, as well as provision of long-term safety at nuclear legacy facilities require the scientific community to develop systems of engineered safety barriers preventing radionuclide releases into the environment. In the near future, at least 70 storage facilities for non-removable $R W$ will require the installation of such barrier systems. The quality of barrier materials constituting to the system of engineered safety barriers (EBS), including their ability to provide a uniform backfilling of cavities inside the structures, is viewed as an important design parameter requiring proper assessment both under the production control of materials and quality control of designed EBS, including relevant in situ testing.
\end{abstract}

Keywords: radioactive waste, barrier clay material, decommissioning, isolation of NRHF, PUGR, IF NRRW, fluidity, flowability, clay powder, bentonite, angle of repose, engineered safety barrier.

\section{Introduction}

At present time, during the decommissioning of production uranium-graphite reactors (PUGR) of widespread application is a EBS construction method suggesting that reactor shaft and out-of-reactor premises, gaps between waste containers at radioactive waste disposal facilities (RWDW) are backfilled with barrier materials [1] based on clay powders of different composition and characteristics.

The following factors are considered as most important ones during the backfilling process: low level of dusting during unloading and backfilling operations and no segregation by particle size distribution. In terms of RW isolation, the material ability providing its even distribution during the backfilling and void-free filling of the internal space inside the cavities is seen as a key characteristic of barrier materials. This characteristic can be called the volumetric mobility of clay powder.

In recent years, the flow function indicator has been introduced to the engineering specifications 
of barrier materials and mixtures to describe the material ability to provide a void-free filling of the internal spaces having different geometry and volume [2]. The flow function can be specified based on uniaxial unconfined compression tests with the resistance of a free-standing powder column being measured.

It should be noted that the flow function indicator is neither mentioned in the Russian normative, technical and methodological documentation nor relevant manuals for the operation of measuring instruments included into the State Register of Measuring Instruments (the State Register). At present time, no measurement methods have been developed for this indicator, it's neither possible to test the instruments that measure the flow function in the regional department of the State Center for Standardization, Metrology and Testing (CSM) nor in other duly accredited legal entities, there are no state standard samples (SSS) on sale.

This article overviews the methods used to determine the volumetric mobility of clay powders and evaluates the influence produced on this parameter by mineral and fractional composition and moisture content of barrier materials.

\section{Existing methods for powder mobility assessment}

The volumetric mobility of clay powders depends on the density, size and shape of particles, the state of their surface, humidity and other properties. For example, increased dispersion results in a decreased volumetric mobility due to an increase in the total contact surface. Increased moisture content also reduces the clay powder mobility. None of the existing methods can fully characterize all the mobility properties of a powder mass, nevertheless, this indicator should be evaluated to plan relevant operations on the establishment of internal EBS assuming that a void-fee backfilling method is applied to fill the reactor space, at-reactor spaces, tanks, buildings and structures during the isolation of facilities holding special (non-removable) radioactive waste (IF NRRW) and the inter-container space at RW storage and disposal facilities.

Since the composition of barrier materials is based on clay powders, let's first consider the term of the soil fluidity index provided in GOST 25100 (p. A.18, Appendix A) [3]. Its provisions state that it is an indicator showing the state (consistency) of clay soils being equal to the ratio of difference between natural moisture and moisture at the rolling boundary to the plasticity index. This indicator is calculated, whereas the plasticity limits are characterized with a certain laboratory error, which entails some misconception about the former one [4].
The widespread use of powders in various industries has prompted the development of numerous methods designed to evaluate their mobility. Today, 4 main methods are used in production industry:

- flow rate control [5];

- compressibility factor and the Hausner ratiobased method;

- shear cell method;

- method based on the angle of repose.

Depending on the tested item and industrial sector, applied is one of these methods or their many varieties. Provided below is a more detailed discussion of the existing methods allowing the evaluation of the volumetric mobility, the scope of their application and the equipment required.

\section{Flow rate}

Flow rate measurements involving a material flowing through a hole clearly demonstrate the powder mobility. However, in this case it is essential to maintain a continuous flow.

Even among free-flowing materials, there are some samples leaking out with a pulsating flow. The flow rate can change as the container gets empty. In this case, hole-through flow rate measurements are used for easily flowing materials, for example, metal powders and their mixtures, containing nonmetallic components. In this case, the flow rate is measured using a calibrated funnel (Hall device) in accordance with GOST 20899-98 (ISO 4490-78) provisions [6].

Unlike metal powders, with relevant fluidity measurements to be performed according to GOST 20899, a number of factors that can have a dramatic effect on the measurements is essential for powders made from other materials, including:

- diameter and shape of the hole;

- the type of container material (metal, glass, plastic); - diameter and height of the powder layer.

Literature sources discuss a variety of different methods used to measure the flow rate through a hole. For example, for pharmaceutical powders, their ability to flow out of a hole at a certain rate is called flowability and is expressed in the number of seconds in which $50 \mathrm{~g}$ of powder can flow out through a calibrated hole of a conical funnel with a diameter of $2.5 \mathrm{~mm}$ [7].

In general, the techniques can be classified according to three main features [8]:

- type of the powder container;

- the size and shape of the hole;

- the method applied to measure the powder outflow rate.

No general scale is applied to measure the mobility as a function of the outflow rate, since it largely depends on the applied measurement method. 
This technique is considered inapplicable for materials prone to cohesion, i.e., for barrier materials based on clay minerals.

\section{Compressibility factor and Hausner ratio}

The approach involving the application of the compressibility factor and the Hausner ratio closely related to the former one is considered as a simple, fast and common method used to characterize powder mobility in the pharmaceutical industry. The compressibility factor is an indirect measure of bulk material density, size and shape, surface area, cohesiveness and moisture content. The compressibility coefficient and the Hausner ratio are calculated through the measured powder volumes under free filling mode and its compaction $[8,9]$.

Although there are several methods allowing to calculate the compressibility factor and the Hausner ratio, the key approach involves powder volume measurement before shrinkage $\left(V_{0}\right)$ and the final powder volume after shrinkage or compaction $\left(V_{\mathrm{K}}\right)$. These values are calculated using the following formulas:

$$
\begin{gathered}
\text { Compressibility factor }=100 \times\left(V_{0}-V_{k}\right) / V_{0}, \\
\text { Hausner ratio }=V_{k} / V_{0} .
\end{gathered}
$$

Table 1 presets the flowability scale developed by Carr [8]: it specifies the qualitative indicator for the flowability degree depending on the Hausner ratio.

Table 1. Degree of flowability and Hausner ratio

\begin{tabular}{|l|c|}
\hline Flowability & Hausner's ratio \\
\hline Very good & $1.00-1.11$ \\
\hline Good & $1.12-1.18$ \\
\hline Satisfactory & $1.19-1.25$ \\
\hline Medium & $1.26-1.34$ \\
\hline Unsatisfactory & $1.35-1.45$ \\
\hline Bad & $1.46-1.59$ \\
\hline Very bad & $>1.6$ \\
\hline
\end{tabular}

The measurements of powder volumes before and after shrinkage or its density assuming free backfilling and shrinkage are influenced by:

- the diameter of the cylinder applied;

- the number of impacts before reaching the considered density after shrinkage;

- the mass of the material used in the test;

- rotation of the sample during its compaction.

\section{Shear cell method}

To provide a fundamental basis for the study of powder mobility and the hopper designs, some shear devices have been purposely developed for different powder types. When applied, the mobility property is defined as a function of compaction load, time and other environmental factors. The essence of the mechanism used to assess the mobility by the shear cell method is presented in detail in the publications of D. Schulze $[10,11]$. One of the types of a shear cell is a cylindrical one, which forms a plane in a horizontal section indicating the displacement between the lower solid base and the upper movable part of the ring. After powder layer compaction, the force required to shift the powder layer by the movement of the upper ring is measured using the shear cell. However, in this case powder layer is displaced inhomogeneously, since the particles of the material on the outer part of the ring are shifted more than the particles in the inner region which is seen as a disadvantage of this method associated with the configuration of the cell. D. Schulze has introduced a powder mobility classification system depending on the flow function index ff. The indicator is defined as a ratio between the strain applied to provide the primary compaction of the sample in the cylindrical cell $\sigma_{1}, \mathrm{~Pa}$, to the strain at which the sample is destroyed $\sigma_{c}, \mathrm{~Pa}$ :

$$
f f=\sigma_{1} / \sigma_{c} .
$$

The higher is the flow function $f f$, the better the material flows (Table 2).

\section{Table 2. Classification of powders according to their fluidity [10]}

\begin{tabular}{|c|c|}
\hline Flow function & Characteristics of the material \\
\hline$f f<1$ & Non-flowing \\
\hline $1<f f<2$ & Very sticky \\
\hline $2<f f<4$ & Sticky \\
\hline $4<f f<10$ & Easy flowing \\
$10<f f$ & Free flowing \\
\hline
\end{tabular}

Opportunities providing high-level of control over the testing process are seen as a significant advantage of the shear cell method. At the same time, this method requires expensive equipment, development and validation of relevant techniques. In world practice, this method is widely demanded in the pharmaceutical industry, i.e., it is in this area that the volumetric powder mobility is seen as a most important process parameter and it should be measured to provide the packaging of medicines and drugs in sachets, capsules, etc.

There are some studies $[2,12]$ suggesting that the flow function of barrier materials can be measured via the shear cell method described by D. Schulze. The tests used a BROOKFIELD powder flow analyzer designed to describe the flow process in vaults, 
hoppers, feeding devices, filling machines and other similar equipment applied in the pharmaceutical industry. However, for EBS, it is important to evaluate powder behavior in the process of its distribution inside the cavities of various configurations at the time of filling and not its ability to pour out of the hopper. Thus, the flow function cannot serve as a criterion that can be used to assess the quality of selected barrier materials and the feasibility of their application in the construction of EBS for RW isolation purposes.

\section{Angle of repose}

The angle of repose is used to describe the volumetric mobility of a solid stream. It is defined as the angle of inclination between the surface of a loosely filled soil and the horizontal plane. It results from the particle friction forces balancing their gravitational component [13]. The smaller is the angle of repose, the greater is the volumetric powder mobility [14].

This method found wide application in various industries. For example, for soils, the known methods are described in RSN 51-84 [15] (for sands) and GOST 27802 [16] (for alumina).

Angle of repose measurements are also applicable in pharmaceuticals. The method is discussed in OFS.1.4.2.0016.15 Flowability of Powders [17]. However, in this monograph, the angle of repose stands for the angle formed by the cone-shaped pyramid of a material obtained under certain experimental conditions, relative to the horizontal surface. Therefore, the pharmacopeial angle of repose accounts for $180^{\circ}$ minus the angle of repose determined in soil science. Hereinafter, we will call the angle of repose determined in accordance with the Pharmacopoeia Monograph "the natural cone angle of the powder".

OFS.1.4.2.0016.15 introduces a powder flowability scale. It is expressed as a dependence between the quality indicator for the flowability level and the natural cone angle of the powder (Table 3). The flowability level is a complex process characteristic that depends on the dispersion rate and the shape of particles, residual moisture and granulometric composition of the powder system.

Table 3. Flowability level of powders and the natural cone angle of powders [17]

\begin{tabular}{|c|c|}
\hline Flowability level & Natural cone angel of the powder, degree \\
\hline Very good & $25-30$ \\
\hline Good & $31-35$ \\
\hline Satisfactory & $36-45$ \\
\hline Unsatisfactory & $46-55$ \\
\hline Bad & $56-65$ \\
\hline Very bad & More than 66 \\
\hline
\end{tabular}

Devices (instruments) are not required to determine the angle of repose. Relevant tests can be performed by a specialist of a technical control department (TCD) during the acceptance testing of a barrier material or by an engineer and technical worker (ETW) immediately at the site where the operations on the establishment of internal EBS are implemented.

Thus, out of all the methods considered to measure the volumetric mobility of barrier mixtures, it seems reasonable to select the one that would characterize the behavior of a powder on a plane during its pouring. In this regard, the angle of repose method was chosen as the only one allowing to estimate the distribution of particles over the surface and considered as potentially applicable for clay powders.

\section{Experimental part}

The existing methods used to measure the bulk mobility of powders were evaluated and it was found that the identification of the natural cone angle should be considered as a most feasible way of characterizing the flow properties of barrier materials during the establishment of internal engineered barriers and evaluating the opportunities for void-free filling of the internal spaces. Angles of repose for clay powders of various mineral nature, considered as potential barrier materials for the isolation and disposal of RW, have been evaluated under this study. The choice of this method was based on the equipment used and its advantage suggesting that the flowability could be qualitatively assessed based on the measurements.

\section{Materials and methods}

The study involved eight samples: vermiculitelike material, bentonite and kaolin clays, as well as mixtures based on them with given characteristics presented in Table 4.

The tests were performed in a certified laboratory run by LLC Bentonit of Khakassia using measuring instruments included into the State Register and undergoing regular verification. The angle of the natural cone was measured based on two approaches:

1. mechanized, according to GOST 27802,

2. using a universal powder analyzer PowderPro M1 (included into the State Register) (Figure 1). Sample preparation was performed in accordance with GOST 25389 [19]. Moisture content was measured in accordance with GOST 28177 [20]. During the tests, the granulometric composition of each material was additionally evaluated in accordance with GOST 28177. 


\section{Table 4. Types of tested materials and their initial characteristics}

\begin{tabular}{|c|c|c|c|}
\hline $\begin{array}{l}\text { Sam- } \\
\text { ple № }\end{array}$ & Clay & $\begin{array}{l}\text { Material } \\
\text { type }\end{array}$ & \begin{tabular}{|c} 
Class of \\
particles, $\mathrm{mm}$
\end{tabular} \\
\hline 1 & \multirow{3}{*}{$\begin{array}{l}\text { Bentonite, 10th Khutor } \\
\text { deposit }\end{array}$} & Clay powder & $\leqslant 0.16$ \\
\hline 2 & & Pellets & $0.63-2.0$ \\
\hline 3 & & Grit & $0-1.0$ \\
\hline 4 & $\begin{array}{l}\text { Vermiculite-like material*, } \\
\text { Kovdor deposit }\end{array}$ & Clay powder & $\leqslant 0.16$ \\
\hline 5 & Kaolin, B. Murt deposit & Clay powder & $\leqslant 0.16$ \\
\hline 6 & $\begin{array}{l}\text { Mixture of kaolin ( } 67 \%) \text {, } \\
\text { bentonite }(29 \%) \text { and vermi- } \\
\text { culite-like material ( } 4 \%)\end{array}$ & Clay powder & $\leqslant 0.16$ \\
\hline 7 & $\begin{array}{l}\text { Mixture of kaolin (70\%) and } \\
\text { bentonite (30\%) }\end{array}$ & Clay powder & $\leqslant 0.16$ \\
\hline 8 & $\begin{array}{l}\text { Mixture of kaolin (30\%) and } \\
\text { bentonite }(70 \%)\end{array}$ & Clay powder & $\leqslant 0.16$ \\
\hline
\end{tabular}

*This material cannot be called vermiculite according to detailed mineralogical studies summarized in [18].

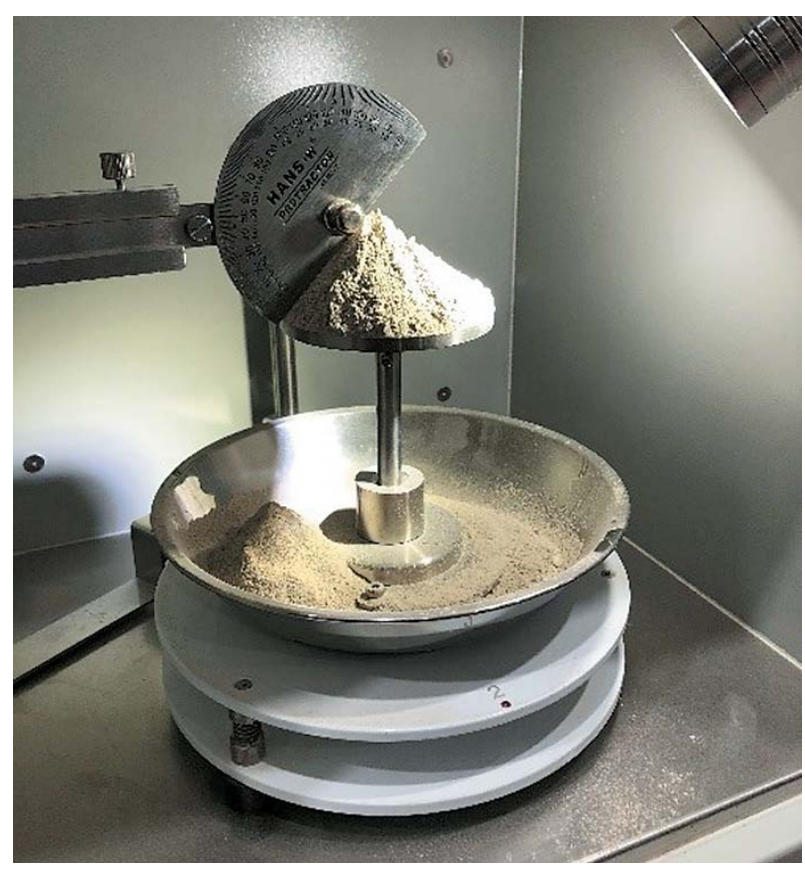

Figure 1. Natural cone angle measurements for sample No. 6 using a universal powder analyzer PowderPro M1

In total, three series of experiments were implemented to reveal the dependences between the natural cone angle and the mineral composition, moisture content in the material, its granulometric composition.

\section{Research results and their discussion}

The first experiment, involved samples 1, 4-8 (Table 4) available in the form of clay powders of similar granulometric composition. The moisture content of the samples was reduced to $4 \pm 1 \%$.
Evaluated data on the natural cone angle for clay powders of raw clay materials (Figure 2) showed that its values were falling within the range of 46.150.6 degrees. If we classify the flowability level according to the natural cone angle in keeping with relevant provision presented in GPS.1.4.2.0016.15 (Table 3), then all tested clay powders would demonstrate an unsatisfactory flowability level. Evaluated clayey mixtures have also revealed some unsatisfactory flowability levels which nevertheless turned out to be lower than those of the original components. It should be also noted that in case of clay mixtures, the natural cone angle was not additive.

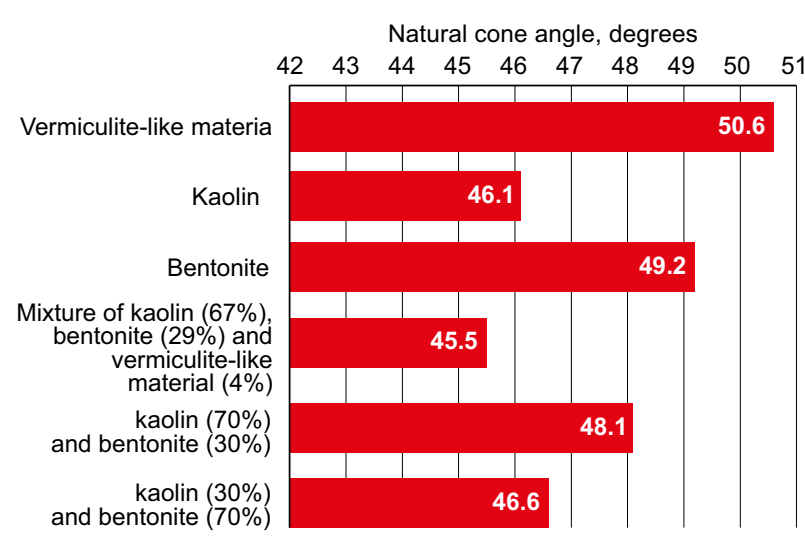

Figure 2. Natural cone angle for samples with different mineral composition

To assess the influence of moisture content of the bulk material, product samples 1-3 were manufactured based on bentonite clay (Table 4) with a moisture content of $6-10 \%$ at a step of $2 \%$. Since the moisture content was decreased using a drying cabinet at a temperature of $(100 \pm 10)^{\circ} \mathrm{C}$, a step of $2 \%$ was conditionally set. Therefore, before testing, each sample was measured to identify its moisture content.

Analysis of the results obtained (Figure 3) showed that, regardless of the granulometric material composition (clay powder, grit, pellets), the moisture content of the samples had important effect on the natural cone angle. At the same time, the maximum moisture content providing the minimum natural cone angle was identified. Further decrease in the moisture content did not produce any significant effect on it. Pellets and grit with a moisture content of less than $8 \%$ demonstrated satisfactory flowability level according to the classification presented in Table 3. Powders with such a moisture content have demonstrated an unsatisfactory flowability level: the measured values appeared to be borderline, i. e., to improve the powder distribution, additional action was required - stirring or vibration. 


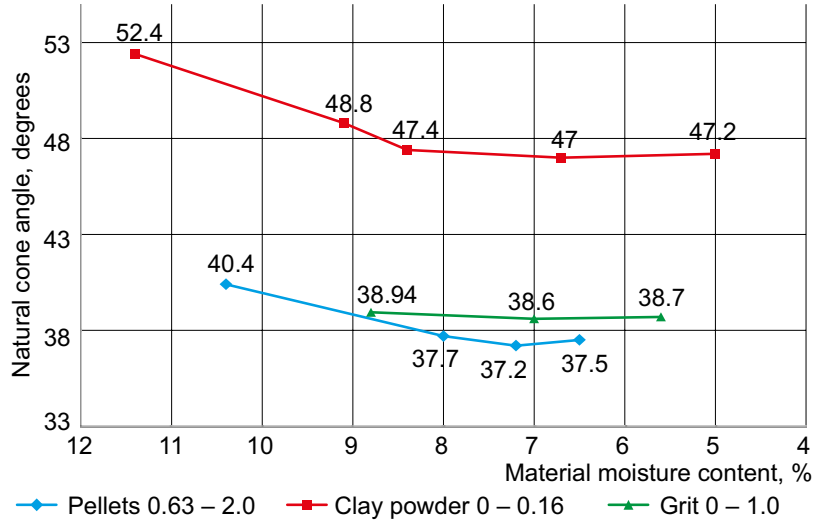

Figure 3. Dependence between the natural cone angle, moisture content and material size

To assess the effect of the particle size distribution on the natural cone angle, sample 3 was taken (grains of bentonite clay with a moisture content of $6 \%$, particle class $0-1 \mathrm{~mm}$ ) and segregated into different fractions. Of these, 10 testing samples were formed involving different particle size ratios. The experiments showed that the grit had a satisfactory flowability level regardless of the particle size distribution, and to achieve the lowest possible natural cone angle, the material composition should predominantly involve particle fractions of $1 \mathrm{~mm}$ or more (Figure 4). Thus, a significant decrease in the natural cone angle was observed if the content of $1 \mathrm{~mm}$ pellets was not less than $25 \%$. The equilibrium number of classes in the mixture did not affect the decrease in its.

It was also shown that the more is the abundance of $0.4 \mathrm{~mm}$ class particles in the mixture, the bigger is the natural cone angle.

\section{Conclusion}

The volumetric mobility of bulk materials is much needed to be measured during the development of internal EBS for PUGR, IF NRRW and RWDF, including the development of relevant designs, EBS production and installation. The measurement results are affected by relevant measurement methods, as well as such parameters as moisture content, grain size composition, surface features and other material properties.

The so-called flow function is currently provided for under engineering specifications for barrier materials, which is an indicator that can be identified via the shear cell method and represents the gravity-driven ability of clay powder to flow out of a silo. The flow function measurements are hampered by the lack of accredited testing methods and instruments included into the State Register.

The angle of repose is considered as the simplest and most effective way that can be applied to assess the ability of a mix to spread over the surface during the backfilling operations. This indicator can be measured by domestically produced and foreign devices available on the market and included into the State Register.

The greater is the angle of repose for a barrier material, the less are the gaps left after the installation of internal engineered barriers at PUGR, IF NRRW, RWDF, etc. Nevertheless, the numerical value of this indicator required to achieve an adequate backfilling capacity is subject to discussion.

According to the experimental data, the natural cone angle for the powders currently used in the production of clay-based engineered barriers amounts to $46.1-50.6$ degrees regardless of the mineral composition. These values demonstrate an unsatisfactory (the angle of repose is 129.4138.4 degrees, respectively) flowability level, thus, requiring some additional mixing and the application of vibration technologies, according to the classification provided in OFS.1.4.2.0016.15.

For bentonite pellets (with a particle size of 0.63 $2.0 \mathrm{~mm}$ ) and grit (with a particle size of $0-1 \mathrm{~mm}$ ), the

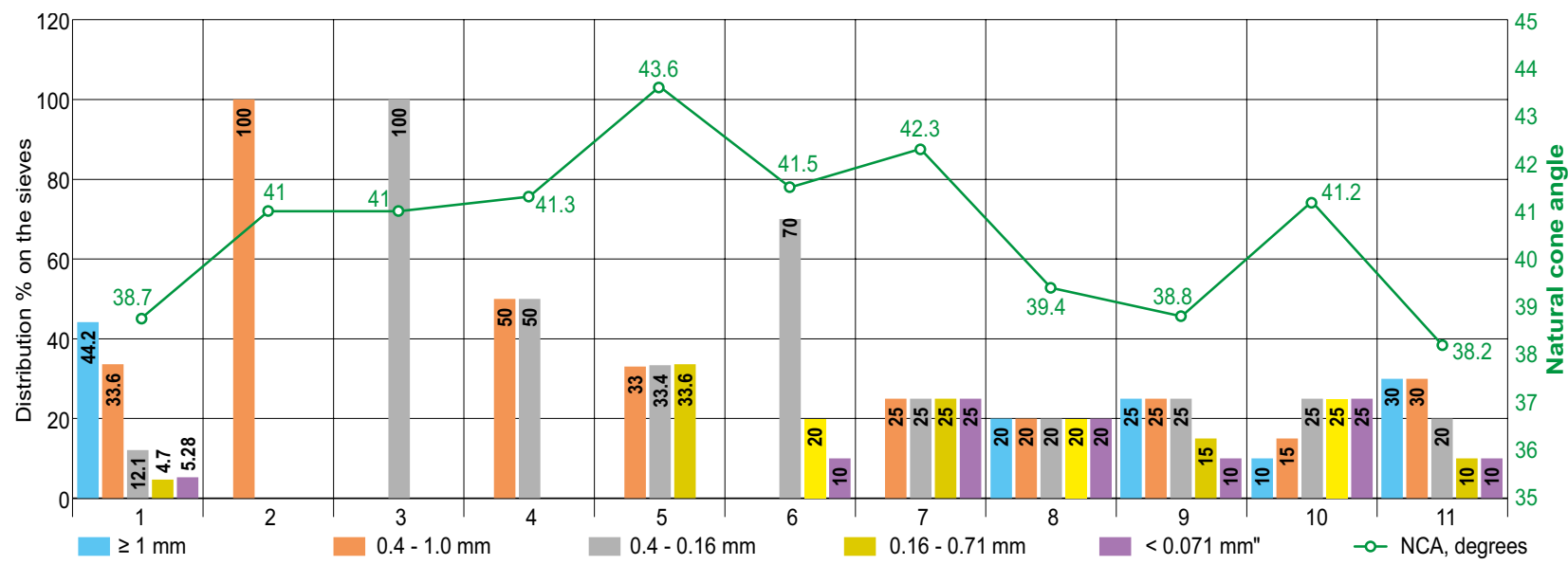

Figure 4. Dependence between the natural cone angle and the particle size distribution 
natural cone angle falls in the range between 37.240.4 degrees (the natural repose angle amounts to 139.6-142.8 degrees), which is significantly lower than the values obtained for clay powders. In keeping with the material classification system according to the flowability level, the result for granules and grit are considered as satisfactory.

However, it cannot be argued that the indicated classification according to the flowability level is applicable in case of facilities intended for RW isolation and disposal. No matter how high is the angle of repose (or small is the natural cone angle), in case of gravity-driven filling with the barrier material, unfilled cavities inevitably remain on the sides of the cone. Currently there are some methods in place providing more effective forced backfilling of the internal spaces at PUGR, IF NRRW and RWDF that have found quite wide application: pneumatic backfilling and mechanical dispersion. Under these backfilling methods, the volumetric mobility of the powders appears to be not critical at all, i. e., cavityfree filling is provided by the equipment used.

Measurements focused on the angle of repose index can be recommended for inclusion into the scope of acceptance and input quality control of barrier materials designed to fill the internal spaces of PUGR, IF NRRW and RWDF by gravity, instead of the flow function indicator. For barrier materials, filled up with the use of pneumatic transport, augers, sprayers, vibration compactors, it seems sufficient to regulate only such indicators as particle size distribution and moisture content.

Selection of proper quality indicators for claybased barrier materials that would provide high EBS performance in terms of their isolating functions, standardization and certification of relevant measurement methods is seen as part of an integrated approach providing scientific and technological support for the decision-making on the selection of appropriate clay materials for the decommissioning of nuclear and radiation hazardous facilities, RW isolation and disposal.

\section{Acknowledgment}

The study was partially performed under the IGEM RAS's State Assignment (research topic 121041500220-0).

\section{References}

1. Ilyina O. A., Lundin D. S., Proskurin D. V., Vedernikova M. V., Biryukov D. V. Materialy i tekhnologii dlya radikal'nogo uluchsheniya gidroizoliruyushchikh kharakteristik khranilishch RAO [Materials and Technologies Providing Radical Improvement of RW
Storage Facility Waterproofing Capacities]. Radioaktivnye otkhody - Radioactive Waste, 2021, no. 1 (14), pp. 51-62. DOI: 10.25283/2587-9707-2021-1-51-62. 2. Martynov K. V., Zakharova E. V., Dorofeev A. N., Zubkov A. A., Prishchep A. A. Use of Clay Materials in the Construction of Protective Barriers at Radiation Hazardous Facilities. Radioaktivnye otkhody Radioactive Waste, 2020, no. 3 (12), pp. 39-53.

3. GOST 25100. Grunty. Klassifikatsiya [Soils. Classification].

4. Zdobin D. Yu. Semenova L. K. Pokazatel' tekuchesti konsistentsiya - osnovnyye fiziko-khimicheskiye pokazateli sostoyaniya gruntov [Indicator of fluidity consistency - the main physical and chemical indicators of the soils state]. Elektronnyy zhurnal Teoriya i praktika izyskaniy - Electronic journal Theory and Practice of Research, 2018. URL: https://www.geoinfo.ru/product/zdobin-dmitrij-yurevich/pokazateltekuchesti-i-konsistenciya-osnovnye-fiziko-imicheskie-pokazateli-sostoyaniya-gruntov-37957.shtml (accessed 16.12.2020).

5. Frolov Yu. G. Kurs kolloidnoy khimii. Poverkhnostnyye yavleniya $i$ dispersnyye sistemy. Uchebnik dlya vuzov [Colloidal Chemistry Course. Surface Phenomena and Dispersed Systems. Textbook for universities]. Moscow, Khimiya Publ., 1982. 400 p.

6. GOST 20899-98 (ISO 4490-78). Poroshki metallicheskiye. Opredeleniye tekuchesti s pomoshch'yu kalibrovannoy voronki (pribora Kholla) [Metal powders. Fluidity measurements using a calibrated funnel (Hall device)]. Moscow, IPK Publishing house of standards Publ., 2001. 9 p.

7. Gavrilov A. S. Izgotovleniye lekarstvennykh preparatov. Uchebnik [Drugs Manufacturing. Textbook]. Moscow, GEOTAR-Media Publ., 2010. 624 p.

8. Gosudarstvennaya farmakopeya Respubliki Belarus'. T. 2. Kontrol' kachestva vspomogatel'nykh veshchestv i lekarstvennogo rastitel'nogo syr'ya / UP Tsentr ekspertiz $i$ ispytaniy $v$ zdravookhranenii [State Pharmacopoeia of the Republic of Belarus. Volume 2. Quality control of excipients and medicinal plant materials / UE Center for Expertise and Testing in Health Care]. Under general edt. of A. A. Sheryakov. - Molodechno, Printing House Pobeda Publ., 2008. 472 p.

9. Shimko O. M., Khishova O. M. Vliyaniye kontsentratsii laktozy na tekhnologicheskiye svoystva travy lapchatki beloy [Influence of lactose concentration on the process properties of the Potentilla white herb]. Vestnik farmatsii - Bulletin of Pharmacy, 2010, no. 3 (49), pp. 85-91.

10. Schulze D. Flow properties of powders and bulk solids (fundamentals). Powder Technol., 2010, no. 65, pp. 321-333.

11. Schulze D. Fliesst nicht gibt's nicht. Kunststoffe International, 2012, vol. 102, no. 1S, pp. 19-21. 
12. Zakharova E. V., Martynov K. V. Trebovaniya k bar'yernym glinistym materialam dlya zakhoroneniya i konservatsii radiatsionno-opasnykh ob"yektov [Requirements for Barrier Clay Materials Intended for the Disposal and Conservation of Radiation Hazardous Facilities]. VI Rossiyskaya Shkola po glinistym mineralam Argilla Studium-2019 i IV Rossiyskoye Soveshchaniye po glinam i glinistym mineralam GLINY-2019 [Clays and Clay Minerals: VI Russian School of Clay Minerals Argilla Studium - 2019 and IV Russian Meeting on Clays and Clay Minerals CLAY - 2019. Proceedings]. Moscow, IGEM RAS Publ., 2019. Pp. 257-259.

13. Trofimov V. T., Korolev V. A., Voznesensky E. A., Golodkovskaya G. A., Vasilchuk Yu. K., Ziangirov R. S. / Edited by Trofimov V. T. / Gruntovedeniye [Soil science] 6th ed., revised and enlarged - M.: Publishing house of Moscow State University, 2005. - $1024 \mathrm{p}$.

14. Kaganer M. G. Teplovaya izolyatsiya v tekhnike vysokikh temperatur [Thermal Insulation in High Temperature Engineering]. Moscow, Mashinostroyeniye Publ., 1966. 85 p.

15. RSN 51-84. Inzhenernyye izyskaniya dlya stroitel'stva. Proizvodstvo laboratornykh issledovaniy fiziko-mekhanicheskikh svoystv gruntov [Engineering Surveys for Construction. Laboratory studies of physical and mechanical soil properties]. Moscow, MosCTISIZ Publ., 1984. 38 p.

16. GOST 27802-93 (ISO 902-76). Glinozem. Metod opredeleniya ugla yestestvennogo otkosa [Alumina. Measurement method for the angle of repose]. Moscow, IPK Izdatel'stvo standartov Publ., 1995. 6 p.

17. Gosudarstvennaya farmakopeya Rossiyskoy Federatsii [State Pharmacopoeia of the Russian Federation]. In 4 volumes. XIV edition. Vol. 2. Moscow, 2018. Pp. 2188-2194.

18. Semenkova A. S., Ilyina O. A., Krupskaya V. V., Zakusin S. V., Dorzhieva O. V., Pokidko B. V., Romanchuk A. Yu., Kalmykov S. N. Sorbtsiya radionuklidov na glinistykh mineralakh - komponentakh inzhenernykh bar'yerov bezopasnosti [Sorption of radionuclides on clay minerals - components of engineered safety barriers]. Vestnik Moskovskogo Universiteta. Seriya 2. Khimiya - Moscow University Bulletin. Series 2. Chemistry, 2021, vol. 62, no. 5, pp. 425-434. 19. GOST 25389-93 (ISO 802-76) as amended. No. 1. Glinozem. Podgotovka proby $k$ ispytaniyu [Alumina. Sample preparation for testing]. Moscow, IPK Izdatel'stvo standartov Publ., 1998. 8 p.

20. GOST 28177-89. Gliny formovochnyye bentonitovyye. Obshchiye tekhnicheskiye usloviya [Bentonite molding clays. General technical specifications]. Moscow, IPK Izdatel'stvo standartov Publ., 2003. 22 p.

\section{Information about the authors}

Maryinskikh Svetlana Georgievna, Ph.D. in Biology, Deputy Director for Quality, "Bentonite Company” Ltd (office 24, 12/1, Tverskaya st., Moscow, 125009, Russia), Associate Professor of the General and Special Chemistry Department, FSBEI of HE “Industrial University of Tyumen” (38, Volodarskogo st., Tyumen, 625000, Russia),e-mail: marinskih@bentonit.ru.

Zhigarev Vasily Valerievich, Quality Director, “Bentonite Company” Ltd (office 24, 12/1, Tverskaya st., Moscow, 125009, Russia), e-mail: zhigarev@bentonit.ru.

Ilyina Olga Aleksandrovna, Consultant, "Bentonite of Khakassia” Ltd (11A, Maxim Gorky st., Chernogorsk, Republic of Khakassia, 655162, Russia), e-mail: ilina@b-kh.ru.

Krupskaya Victoria Valerievna, Ph.D. in Geological and Mineralogical Sciences, Senior Researcher, Nuclear Safety Institute of the Russian Academy of Sciences (52, Bolshaya Tulskaya st., Moscow, 115191, Russia), e-mail: krupskaya@ruclay.com. Senior Researcher, Institute of Geology of Ore Deposits, Petrography, Mineralogy, and Geochemistry of the Russian Academy of Sciences (35, Staromonetny lane, Moscow, 119017, Russia).

\section{Bibliographic description}

Maryinskikh S. G., Zhigarev V. V., Ilyina O. A., Krupskaya V. V. Assessing the mobility of clay materials used in the construction of engineered safety barriers for radioactive waste disposal. Radioactive Waste, 2021, no. 3 (16), pp. 51-60. DOI: 10.25283/2587-9707-2021-3-51-60. (In Russian). 